\title{
Theoretical Aspects of Economic Balanced Scorecard Analysis
}

\author{
Sergey Ivanovich Krylov \\ Department of Accounting, Analysis and Audit \\ Ural Federal University, Russian Federation \\ E-mail: zali6770@yandex.ru
}

Received: Nov. 8, 2013 Accepted: January 25, $2014 \quad$ Published: June 1, 2014

doi:10.5296/ajfa.v6i1.4821ＵRL: http://dx.doi.org/10.5296/ajfa.v6i1.4821

\begin{abstract}
The author proposes theoretical and methodological aspects of the applied strategic analysis (ASA) as a new instrument of the balanced scorecard (BSC) comprehensive study of the organization economic activity. The ASA concept has resulted from the further development of the BSC concept which defines a set of the analyzed indicators and the analysis sequence. Such are the main ASA objectives: comparative evaluation of the BSC data, diagnostics of the BSC data divergence and forecast of the BSC data. All the objectives are closely interrelated, as every coming problem entails from the previous one. The principle of the ASA implementation, a deduction principle, is understood as a research, firstly, of the general BSC indicators, then - specific ones. The basic ASA applications are as follows: analysis of financial data, analysis of customers' data, analysis of the internal business processes data and analysis of the personnel training and development.
\end{abstract}

Keywords: Balanced Scorecard, Applied Strategic Analysis, Comparative Assessment, Variance Diagnostics, Forecast

JEL Classification: C02, M00, M19, M41 


\section{Introduction}

To enhance strategic management efficiency in difficult conditions of today market economy we need to improve its information-analytical support, to evolve theory, methodology and methods of the overall strategic economic activity aspects to the level of the financial analysis being an efficient research instrument of the financial aspects of the organization economic activity based on the financial indicators and described experience.

One of the leads of further research is the development of the foundations of the applied strategic analysis (ASA) concept, assuming a comprehensive research of strategic aspects of the organization economic activity based on the balanced scorecard (BSC) and considered to facilitate strategic management functions.

It should be taken into consideration that the applied strategic analysis lacks any standard methods as it is applied to the balanced scorecard system special for any particular organization. Hence, The ASA methods are special as well for any particular organization. So it enables to discuss general aspects of the methodology rather than its universal specification.

The paper treats theoretical and methodological aspects of the applied strategic analysis concept as a research instrument of the financial aspects of the organization economic activity by means of the financial indicators of the BSC as well as other aspects of the organization performance by means of other elements of the BSC such as customer, internal business-processes, training and personnel development.

\section{Literature review}

The balanced scorecard concept as an analytical instrument applied in the field of strategic management was developed by American scientists Robert Kaplan and David Norton (1992) at the beginning of the 90s of the XX century evolving both in their works (Kaplan \& Norton, 1996, 2001, 2003, 2004, 2005, 2006, 2008) and those of other scientists studying economics (Friedag \& Schmidt, 2002; Horvath \& Partners, 2004; Maisel, 1992; Norreklit, 2000; Olve, Roy \& Wetter, 2000; Rampersad, 2003), and was multiply tested. At present BSC is considered to be one of the essential instruments of the organization management system (enterprise, firm, company, and business-unit).

The main reason to develop BSC was a contradiction between contingencies aimed at setting up wide competitive opportunities and immobile accounting system (financial accounting system).

Balanced scorecard as a whole is implied as an aggregate of parameters featuring an overall organization performance in up-to-date market economy. It reflects a balance to be brought about between short-term and long-term goals, financial and non-financial indicators, basic and auxiliary parameters, as well as internal and external factors of the organization economic activity.

The scores of the balanced system were formed depending on the outlook and strategic goals of any particular organization and have individual features. They represent a balance between 
external accounting data for the owners (shareholders) and internal characteristics of the most significant business processes, innovations, training and growth that is the balance between the results of the organization performance and future growth. The system comprises a combination of objective quantity estimated data and subjective somewhat arbitrary parameters of future growth.

The main goal of the balanced scorecard is to transform the company strategy into specific tangible objectives, indicators and end up with events.

The BSC scores are selected so that the organization managers and employees focus on the factors to enhance the organization competitiveness, the BSC to be accessible for the employees of all levels. The 'front-end' employees should be well aware of the financial consequences of their decisions and actions, while top managers must be committed to the long-term financial success.

Three scores system group balanced scorecard: cause and effect, results attain factors and interrelation with financial data.

The balanced scorecard comprises four basic interrelated elements: financial indicators, customer, internal business processes ones as well as training and personnel development indicators. The BSC scores enable to characterize comprehensively an activity of commercial, government and non-for-profit organizations, the scores being relatively few (about 25 scores in average, as a rule).

The balanced scorecard is presented in Table 1. 
Table 1. Balanced scorecard of the organization development

\begin{tabular}{|l|l|l|l|l|l|}
\hline \multicolumn{1}{|c|}{ BSC elements } & \multicolumn{1}{|c|}{ Key problem } & $\begin{array}{c}\text { Strategic } \\
\text { goal }\end{array}$ & Indicator & $\begin{array}{c}\text { Target } \\
\text { figure }\end{array}$ & $\begin{array}{c}\text { Strategic } \\
\text { event }\end{array}$ \\
\hline Financial activity & $\begin{array}{l}\text { Which goals do they have } \\
\text { to set coming from the } \\
\text { shareholders and investors } \\
\text { expectations? }\end{array}$ & & & & \\
\hline Customers & $\begin{array}{l}\text { Which goals concerning } \\
\text { customer mix and their } \\
\text { demands do they have to } \\
\text { set to attain financial } \\
\text { goals? }\end{array}$ & & & & \\
\hline $\begin{array}{l}\text { Internal } \\
\text { business-processes }\end{array}$ & $\begin{array}{l}\text { Which goals concerning } \\
\text { business-processes do } \\
\text { they to set to attain } \\
\text { financial and customer } \\
\text { goals? }\end{array}$ & $\begin{array}{l}\text { Which goals concerning } \\
\text { training and personnel } \\
\text { development do they have } \\
\text { to set to attain financial } \\
\text { and customer goals as } \\
\text { well as internal business } \\
\text { processes goals? }\end{array}$ & & & \\
\hline $\begin{array}{l}\text { Training and } \\
\text { personnel } \\
\text { development }\end{array}$ & & & & & \\
\hline
\end{tabular}

To complete a brief description of the balanced scorecard it should be noted, that the BSC concept has matured and has been appreciated by different organizations; it has been completed yet neither in terms of theory nor practical application.

\section{Theory and methodology}

Applied strategic analysis assumes a comprehensive complex research of the strategic aspects of the organization economic activity based on the balanced scorecard.

ASA subject implies balanced scorecard and determining factors.

ASA object refers to as strategic aspects of the organization economic activity.

ASA information support is balanced scorecard as an aggregate of parameters characterizing overall organization economic activity in up-to-date market economy: separate elements, key problems, strategic goals and their values and strategic events as well (Table 1).

A goal of the applied strategic analysis is to form analytical support of the strategic managerial decision taking.

The ASA objectives are: 
1. Comparative assessment of the balanced scorecard.

2. Diagnostics of the balanced scorecard variance.

3. Balanced scorecard forecast.

All of them are interrelated as each consecutive objective follows from the previous one. For example, the diagnostics is exercised on the results of the BSC elements comparative assessment while their forecast takes into account the diagnostics results.

Comparative assessment of the balanced scorecard elements assumes comparison of their outcome and target figures, determination of the BSC real and target figures variance and qualitative characteristics of the variance (Table 2). The qualitative characteristics of the BSC real and target figures variance depends on their value (Table 3).

Table 2. Comparative assessment of the balanced scorecard

\begin{tabular}{|c|c|c|c|c|c|}
\hline \multirow{2}{*}{$\begin{array}{l}\text { Balanced } \\
\text { Scorecard } \\
\text { element }\end{array}$} & \multirow{2}{*}{ Target figure } & \multirow{2}{*}{ Real figure } & \multicolumn{2}{|c|}{ Variance } & \multirow{2}{*}{$\begin{array}{c}\text { Qualitative } \\
\text { variance } \\
\text { characteristics }\end{array}$} \\
\hline & & & absolute & $\%$ & \\
\hline & & & & & \\
\hline
\end{tabular}

Table 3. Estimation of qualitative variance characteristics of the BSC real and target figures

\begin{tabular}{|l|l|}
\hline \multicolumn{1}{|c|}{ Variance value, $\%$} & \multicolumn{1}{c|}{ Qualitative variance characteristics } \\
\hline Up to $\pm 1 \%$ & Fairly small \\
From $\pm 1 \%$ to $\pm 5 \%$ & Essential \\
From $\pm 5 \%$ to $\pm 10 \%$ & Significant \\
From $\pm 10 \%$ to $\pm 20 \%$ & Large \\
$\pm 20 \%$ and higher & Very large \\
\hline
\end{tabular}

Balanced scorecard variance diagnostics is based on the cause and effect ties combining BSC values into the general indicators balanced complex and specifying factors (results attaining factors).

The general indicators as the key results indicators which are characteristic to many industries and organizations are assumed as basic parameters (for example, profitability, market share, customer satisfaction, customer base retaining, personnel competence field) applied for deferred evaluation. The results attaining factors are unique for every deferred specific business-unit evaluation indicators reflecting the strategy applied (for example, profitability financial factors, competition market segments, specific business-units goals, training and personnel development). They disclose how the general indicators are attained. Moreover, at the early stages the general indicators are not sufficient to estimate implementation of the organization strategy. Vice versa, the results attaining factors (for example, production cycle time or faulty products percentage) with appropriate indicators 
missing enable to improve only short-term production processes and do not reflect their impact on the customer base and, consequently, on the financial results.

However, some specific BSC outcome indicators (for example, customer and internal business-processes) may be assumed as factors defining factoring indicators variance of the more general element, for example, financial element).

While diagnosing the BSC indicators variance we are able to find out the results attaining factors having impact on the general or outcome BSC indicators and determine the variance value.

The BSC factoring model comprises the outcome financial BSC indicator as final (more general) indicators and seven levels of the defining factors:

$1^{\text {st }}$ level factors: factorial indicators of the BSC financial element;

$2^{\text {nd }}$ level factors: outcome customer indicators and some outcome indicators of the internal BSC business-processes;

$3^{\text {rd }}$ level factors: customer factorial indicators and some outcome indicators of the internal BSC business-processes;

$4^{\text {th }}$ level factors: some outcome indicators of the internal BSC business-processes and personnel development;

$5^{\text {th }}$ level factors: some factorial indicators of the internal BSC business-processes and personnel development;

$6^{\text {th }}$ level factors: some outcome indicators of the BSC training and personnel development element;

$7^{\text {th }}$ level factors: some factorial indicators of the BSC training and personnel development element.

We can push the analogy further on the five levels of the factors defining the outcome BSC customer variance, three levels of the factors defining the outcome BSC internal business-process indicators variance, and one level of the factors defining the outcome BSC training and personnel development indicators variance (Table 4).

Table 4. The computation results of the factors impaction the outcome BSC indicators

\begin{tabular}{|c|c|c|c|c|c|c|c|c|c|c|c|c|c|}
\hline \multirow{3}{*}{$\begin{array}{c}\text { The outcome } \\
\text { BSC } \\
\text { indicators }\end{array}$} & Absolute & \multicolumn{12}{|c|}{ The factorial indicators impact } \\
\hline & \multirow{2}{*}{ Variance } & \multicolumn{3}{|c|}{ 1st level } & \multicolumn{3}{|c|}{$2^{\text {nd }}$ level } & \multicolumn{3}{|c|}{$\ldots$} & \multicolumn{3}{|c|}{$7^{\text {th }}$ level } \\
\hline & & $\ldots$ & $\ldots$ & $\ldots$ & $\ldots$ & $\ldots$ & $\ldots$ & $\ldots$ & $\ldots$ & $\ldots$ & $\ldots$ & $\ldots$ & $\ldots$ \\
\hline & & & & & & & & & & & & & \\
\hline
\end{tabular}

The appropriate deductions are drawn from the computation results. 
In case of the objective conditions the balanced scorecard forecast is targeted at the primordial determination and/or correction of the target BSC indicators values and either determination of the specific ways of their attainment or the development of the events aimed at the elimination of the variance emerged between outcome and target BSC indicators values in the future. Firstly, the general (outcome) indicators are forecast then the factorial BSC indicators are deducted from them. The results of the forecast BSC indicators values are presented in the form of a table (Table 5).

Table 5. The results of the forecast BSC indicators values

\begin{tabular}{|l|l|l|l|l|l|}
\hline BSC value & Factual value & \multirow{2}{*}{ Target value } & \multicolumn{2}{|c|}{ Variance } & \multirow{2}{*}{ Comments } \\
\cline { 4 - 4 } & & & Absolute & $\%$ & \\
\hline & & & & & \\
\hline
\end{tabular}

The ASA aspects imply proper strategy aspects, tactical aspects and operations aspects. Within strategic ASA aspects evaluated, diagnosed and forecast are final BSC indicators values at the time of the developed strategy functioning i.e. their strategic values. Within tactical aspects of the applied strategic analysis we evaluate, diagnose and forecast interim BSC indicators values by the end of the year, i.e. their tactical values. Within operations aspect of the applied strategic analysis evaluated, diagnosed and forecast are interim BSC indicators values by the end of each month, i.e. their operations values.

All the ASA aspects mentioned are interrelated and agreed: the results of the analysis of the operations BSC indicators values impact on their tactical values and the results of the tactical value analysis impact on the strategic ones.

The instruments of the ASA methods comprise a combination of methods ensuring that the analysis is carried out and its goals are attained. The basic ASA method may include methods of absolute, relative and average values, comparison, grouping, graphical, table and balance methods, as well as factoring, correlation and regression analysis.

The ASA accomplishment principle, a deduction principle presumes, firstly, an investigation of the general BSC indicators, then specific indicators. The principle defines general sequence of the ASA analysis according to the following leads:

1. Analysis of financial indicators.

2. Analysis of customer indicators.

3. Analysis of internal business-processes indicators.

4. Analysis of training and personnel development indicators.

\section{Results}

Each of the basic ASA leads, financial, customers, internal business-processes as well as training and personnel development is represented through the prism of its basic objectives: 


\section{Macrothink}

evaluation, diagnostics and forecast. The ASA commences from the comparative evaluation of the financial indicators and is completed by the forecast of training and personnel development.

In addition, assuming "intersection points" of the basic leads and the most significant objectives as some kind of elements we are able to build a matrix out of the ASA elements (Table 6). The author assumes that the introduced matrix (Table 6) may be considered as a matrix model respectively visualizing their composition and economic contents.

Table 6. ASA elements matrix

\begin{tabular}{|l|l|l|l|}
\hline \multirow{2}{*}{ Basic ASA leads } & \multicolumn{3}{|c|}{ The most significant ASA objectives } \\
\cline { 2 - 4 } & \multicolumn{1}{|c|}{$\begin{array}{c}\text { Comparative } \\
\text { evaluation (1) }\end{array}$} & $\begin{array}{l}\text { Variance diagnostics } \\
(2)\end{array}$ & \multicolumn{1}{|c|}{ Forecast (3) } \\
\hline $\begin{array}{l}\text { Financial } \\
\text { indicators analysis } \\
(1)\end{array}$ & $\begin{array}{l}\text { Comparative } \\
\text { evaluation of } \\
\text { financial indicators }\end{array}$ & $\begin{array}{l}\text { Diagnostics of } \\
\text { financial indicators } \\
\text { variance }\end{array}$ & $\begin{array}{l}\text { Financial indicators } \\
\text { forecast }\end{array}$ \\
\hline $\begin{array}{l}\text { Customer } \\
\text { indicators analysis } \\
(2)\end{array}$ & $\begin{array}{l}\text { Comparative } \\
\text { evaluation of } \\
\text { customer indicators }\end{array}$ & $\begin{array}{l}\text { Diagnostics of } \\
\text { customer indicators } \\
\text { variance }\end{array}$ & $\begin{array}{l}\text { Customer indicators } \\
\text { forecast }\end{array}$ \\
\hline $\begin{array}{l}\text { Analysis of } \\
\text { internal } \\
\text { business-processes } \\
\text { indicators (3) }\end{array}$ & $\begin{array}{l}\text { Comparative } \\
\text { evaluation of } \\
\text { internal } \\
\text { business-processes } \\
\text { indicators }\end{array}$ & $\begin{array}{l}\text { Diagnostics of } \\
\text { internal } \\
\text { business-processes } \\
\text { indicators variance }\end{array}$ & $\begin{array}{l}\text { Internal } \\
\text { business-processes } \\
\text { indicators forecast }\end{array}$ \\
\hline $\begin{array}{l}\text { Analysis of } \\
\text { training and } \\
\text { personnel } \\
\text { development } \\
\text { indicators (4) }\end{array}$ & $\begin{array}{l}\text { Comparative } \\
\text { evaluation of } \\
\text { training and } \\
\text { personnel } \\
\text { development } \\
\text { indicators }\end{array}$ & $\begin{array}{l}\text { Diagnostics of } \\
\text { training and personnel } \\
\text { development } \\
\text { indicators variance }\end{array}$ & $\begin{array}{l}\text { Training and } \\
\text { personnel } \\
\text { development } \\
\text { indicators forecast }\end{array}$ \\
\hline
\end{tabular}

Let $r i j(i=1 \ldots 4, j=1 \ldots 3)$ denote elements of the matrix then we are able to mathematically describe the ASA content by means of the formulae:

$$
R=\sum_{i=1}^{4} \sum_{j=1}^{3} r_{i j}
$$

Where $R$ is a sum of the ASA elements;

$i$ is an index of the basic ASA leads: 1 is financial indicators analysis, 2 is customer indicators analysis, 3 is internal business-processes analysis, 4 is training and personnel development analysis; 


\section{Macrothink

$j$ is an index of the basic ASA objectives: 1 is a comparative evaluation of the BSC indicators, 2 diagnostics of the BSC indicators divergence, 3 is BSC indicators forecast.

The author assumes that the introduced matrix (Table 6) and formulae (1) may be considered as matrix and mathematical models respectively visualizing their composition and economic contents.

Thus, completing overall description of the applied strategic analysis concept and contents we would like to discuss each of its basic leads: financial indicators analysis, customer indicators analysis, internal business-processes analysis and training and personnel development analysis in terms of their goals, separate elements, examples of the indicators analyzed and brief description of the analysis performance.

\subsection{Financial indicators analysis}

The goal of the BSC financial indicators analysis is to form analytical support of taking strategic decisions in finance management.

The basic elements of the financial indicators analysis are as follows:

1. Analysis of assets and investment application efficiency.

2. Analysis of financial risk.

3. Analysis of cash flow.

4. Analysis of earnings costs and profit.

The examples of the analyzed financial indicators are presented in Table 7.

Table 7. Examples of the analyzed financial indicators

\begin{tabular}{|l|l|l|}
\hline \multirow{2}{*}{$\begin{array}{l}\text { Element of the } \\
\text { financial indicators } \\
\text { analysis }\end{array}$} & Indicators analyzed & \multicolumn{2}{|c|}{ Outcome } \\
\cline { 2 - 3 } $\begin{array}{l}\text { 1.Analysis of } \\
\text { assets and } \\
\text { investment }\end{array}$ & $\begin{array}{l}\text { Investment efficiency in } \\
\text { operating activities in terms of } \\
\text { application } \\
\text { efficiency }\end{array}$ & $\begin{array}{l}\text { Sales efficiency; } \\
\text { Net cash flow to sales earnings; } \\
\text { Investment efficiency in } \\
\text { intellectual and human capital in } \\
\text { terms of net sales (or net cash } \\
\text { flow); } \\
\text { Assets efficiency in terms of net } \\
\text { income (or outcome net cash } \\
\text { flow; } \\
\text { Net capital efficiency in terms of } \\
\text { earnings; } \\
\text { Gross sales profit (or earnings) to } \\
\text { average investment in operating } \\
\text { activities; } \\
\text { Sales revenues (or cash inflow) to } \\
\text { average investment in intellectual } \\
\text { and human capital; } \\
\text { Earnings (total cash inflow) to total }\end{array}$ \\
\hline
\end{tabular}




\begin{tabular}{|c|c|c|}
\hline & flow) & $\begin{array}{l}\text { average assets; } \\
\text { Total average assets to average net } \\
\text { capital }\end{array}$ \\
\hline $\begin{array}{l}\text { 2. Financial risk } \\
\text { analysis }\end{array}$ & $\begin{array}{l}\text { Root average square variance } \\
\text { and net sales variation } \\
\text { coefficient (or net cash flow); } \\
\text { Root average square variance } \\
\text { and net income variation } \\
\text { coefficient (or outcome net cash } \\
\text { flow); } \\
\text { Effect of operating leverage; } \\
\text { Effect of financing leverage }\end{array}$ & $\begin{array}{l}\text { Root average square variance and } \\
\text { sales revenues variation coefficient } \\
\text { (or net cash inflow); } \\
\text { Root average square variance and } \\
\text { operating cost variation coefficient } \\
\text { (or net cash outflow); } \\
\text { Root average square variance and } \\
\text { earnings variation coefficient (or } \\
\text { total cash inflow); } \\
\text { Root average square variance and } \\
\text { total expenses variation coefficient } \\
\text { (or total cash outflow); } \\
\text { Proportion of fixed costs in cost of } \\
\text { goods sold; } \\
\text { Proportion of fixed expense in total } \\
\text { expense }\end{array}$ \\
\hline $\begin{array}{l}\text { 3. Cash flows } \\
\text { analysis }\end{array}$ & $\begin{array}{l}\text { Outcome net cash flow; } \\
\text { Net cash flows from operating, } \\
\text { investing and } \\
\text { financing activities; } \\
\text { Net cash flows from sales of } \\
\text { individual products; } \\
\text { Net cash flows from individual } \\
\text { accounts; } \\
\text { Net cash flows from sales of } \\
\text { new products; } \\
\text { Proportion of net cash flow from } \\
\text { sales of new products in net cash } \\
\text { flow from current activities }\end{array}$ & $\begin{array}{l}\text { Total cash inflow and outflow; } \\
\text { Cash inflows and outflows from } \\
\text { operating, investing and financing } \\
\text { activities; } \\
\text { Cash inflows and outflows from } \\
\text { production and sales of individual } \\
\text { product range; } \\
\text { Cash inflows and outflows from } \\
\text { production and sales to individual } \\
\text { accounts; } \\
\text { Cash inflows and outflows from } \\
\text { production and sales of new } \\
\text { products }\end{array}$ \\
\hline $\begin{array}{l}\text { 4. Analysis of } \\
\text { earnings, expense } \\
\text { and profit }\end{array}$ & $\begin{array}{l}\text { Net income; } \\
\text { Pre-tax income; } \\
\text { Net sales; } \\
\text { Net certain products sales; } \\
\text { Net sales from individual } \\
\text { accounts; } \\
\text { Net sales from new products; } \\
\text { Other income; } \\
\text { Net income growth rate to } \\
\text { pre-tax income; } \\
\text { Net sales growth rate to pre-tax }\end{array}$ & $\begin{array}{l}\text { Total earnings; } \\
\text { Total expense; } \\
\text { Total tax expense; } \\
\text { Sales revenues; } \\
\text { Cost of goods sold; } \\
\text { Individual product range sales } \\
\text { revenues; } \\
\text { Cost of individual goods sold; } \\
\text { Sales revenues from individual } \\
\text { accounts; } \\
\text { Cost of goods sold by individual }\end{array}$ \\
\hline
\end{tabular}




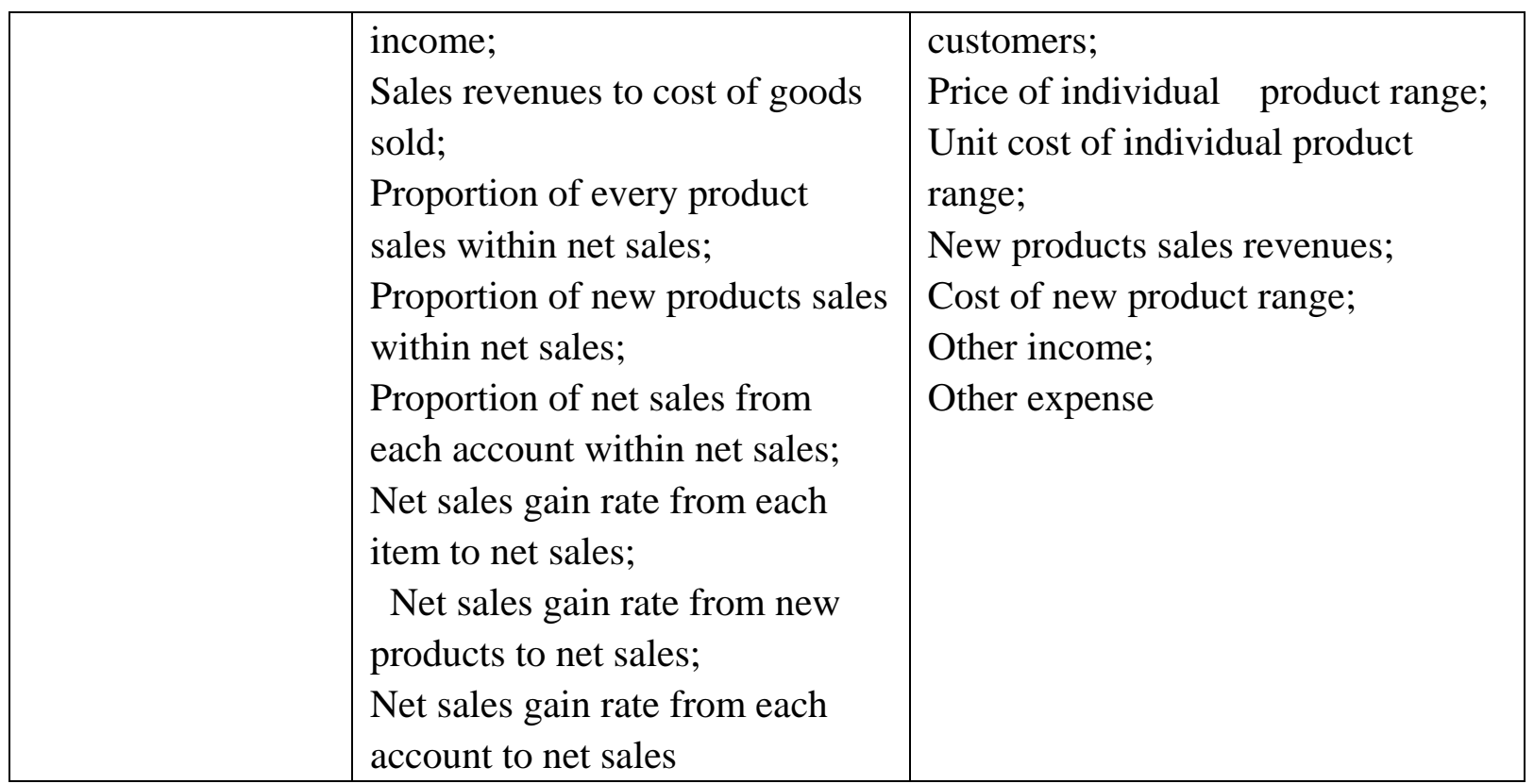

The procedure of BSC financial indicators analysis commences from the analysis of overall organization assets and investment application and their separate items as well as the level of the accompanying financial risk logical within well-known context of risk and profitability correlation. Then analyzed are cash flows generated by economic activity of the organization and by its separate divisions. The analysis is finalized by the study of earnings, expense and income from the organization economic activity including operating and other activities as well as earnings from its certain product range.

\subsection{Customers indicators analysis}

The analysis of the BSC customer indicators is aimed at making up analytical support for taking strategic sales management decisions.

The basic elements of the BSC customer indicators analysis are:

1. Analysis of the customer profitability level.

2. Analysis of the products distribution market share.

3. Analysis of the customer base mix, volume and structure.

4. Analysis of the customer satisfaction level.

The examples of the customer indicators analyzed are presented in Table 8. 


\section{Macrothink}

Table 8. Examples of the customer indicators analyzed

\begin{tabular}{|c|c|c|}
\hline \multirow{2}{*}{$\begin{array}{c}\text { Element of the } \\
\text { customer indicators } \\
\text { analysis }\end{array}$} & \multicolumn{2}{|c|}{ Indicators analyzed } \\
\hline & Outcome & Factorial \\
\hline $\begin{array}{l}\text { 1. Analysis of the } \\
\text { customer profitability } \\
\text { level }\end{array}$ & Sales efficiency (total) & $\begin{array}{l}\text { Sales efficiency to individual } \\
\text { customers; } \\
\text { Sales efficiency of individual } \\
\text { product range; } \\
\text { Sales efficiency of new products; } \\
\text { Sales efficiency of each product }\end{array}$ \\
\hline $\begin{array}{l}\text { 2. Analysis of the } \\
\text { products distribution } \\
\text { market share }\end{array}$ & Company market share & $\begin{array}{l}\text { Individual customer market } \\
\text { share; } \\
\text { Market share of individual } \\
\text { products manufactured; } \\
\text { New products market share }\end{array}$ \\
\hline $\begin{array}{l}\text { 3. Analysis of the } \\
\text { customer base mix, } \\
\text { volume and structure }\end{array}$ & $\begin{array}{l}\text { Proportion of regular customers } \\
\text { within a total number of } \\
\text { customers; } \\
\text { Proportion of new customers } \\
\text { within a total number of } \\
\text { customers; } \\
\text { Proportion of transactions with } \\
\text { regular customers within a total } \\
\text { number of transactions; } \\
\text { Transactions with new customers } \\
\text { within a total number of } \\
\text { transactions; } \\
\text { Proportion of sales to regular } \\
\text { customers within a total number } \\
\text { of sales; } \\
\text { Proportion of sales to new } \\
\text { customers within a total number } \\
\text { of sales; } \\
\text { Absolute and relative growth of } \\
\text { regular, new and total number of } \\
\text { customers; } \\
\text { Absolute and relative growth of } \\
\text { total, regular and new } \\
\text { transactions, } \\
\text { Absolute and relative growth of } \\
\text { total, regular and new sales; } \\
\text { A number of new customers to a } \\
\text { number of potential customers }\end{array}$ & $\begin{array}{l}\text { Total number of customers; } \\
\text { A number of regular customers; } \\
\text { A number of new customers; } \\
\text { A number of potential customers; } \\
\text { Total sales; } \\
\text { Transactions with regular } \\
\text { customers; } \\
\text { Transactions with new } \\
\text { customers; } \\
\text { Total sales; } \\
\text { Sales to regular customers; } \\
\text { Sales to new customers }\end{array}$ \\
\hline
\end{tabular}




\begin{tabular}{|l|l|l|}
\hline $\begin{array}{l}\text { 4. Analysis of the } \\
\text { customer } \\
\text { satisfaction level }\end{array}$ & $\begin{array}{l}\text { Rating of the customer } \\
\text { satisfaction level }\end{array}$ & $\begin{array}{l}\text { Results of customers polled; } \\
\text { A number of repeat businesses }\end{array}$ \\
\hline
\end{tabular}

The procedure of the BSC customer indicators analysis is characterized by a rigorous sequence and commences from the analysis of the customer profitability level. Later analyzed is products distribution market share of the organization. Then the analysis of the customer base mix, volume and structure is performed. Finally, we analyze a level of customer satisfaction.

\subsection{Internal business-processes indicators analysis}

The analysis of the internal business-processes indicators is aimed at making up analytical support for taking strategic production management decisions.

The basic elements of the internal business-processes indicators analysis are:

1. Analysis of the after-sales service indicators.

2. Analysis of the operating process indicators.

3. Analysis of the innovation process indicators.

It should be noted that every element of the internal business-processes analysis such as analysis of the operation process indicators and analysis of the innovation process indicators is sizable and needs to be subdivided into particular sub-elements.

The complex after-sales service indicators analysis comprises the following elements:

1. Analysis of the customer invoicing rate, as well as final payment and differences settlement.

2. Analysis of the due delivered goods upgrade.

3. Analysis of the guaranteed maintenance and repair rate.

4. Analysis of the faulty goods replacement rate (should they be delivered).

The examples of the after-sales service indicators analysis for every complex element are entered into Table 9. 
Table 9. Examples of the after-sales service indicators analysis

\begin{tabular}{|c|c|c|}
\hline \multirow{2}{*}{$\begin{array}{l}\text { Element of after-sales } \\
\text { service indicators } \\
\text { analysis }\end{array}$} & \multicolumn{2}{|c|}{ Indicators analyzed } \\
\hline & Outcome & Factorial \\
\hline $\begin{array}{l}\text { 1. Analysis of the } \\
\text { customer invoicing rate, } \\
\text { as well as final payment } \\
\text { and differences } \\
\text { settlement }\end{array}$ & $\begin{array}{l}\text { Average rate of customer } \\
\text { invoicing; } \\
\text { Average rate of customer } \\
\text { accounts payable; } \\
\text { Average rate of customer } \\
\text { differences settlement }\end{array}$ & $\begin{array}{l}\text { Rate of individual customer } \\
\text { invoicing; } \\
\text { Rate of payment of individual } \\
\text { customer accounts payable; } \\
\text { Rate of individual customer } \\
\text { difference settlement }\end{array}$ \\
\hline $\begin{array}{l}\text { 2. Analysis of the due } \\
\text { delivered goods } \\
\text { upgrade }\end{array}$ & $\begin{array}{l}\text { Average rate of the delivered } \\
\text { goods upgrade }\end{array}$ & $\begin{array}{l}\text { Rate of the goods upgrade } \\
\text { delivered to individual } \\
\text { customers; } \\
\text { Cost of the delivered goods } \\
\text { upgrade }\end{array}$ \\
\hline $\begin{array}{l}\text { 3. Analysis of the } \\
\text { guaranteed maintenance } \\
\text { and repair rate }\end{array}$ & $\begin{array}{l}\text { Absolute and relative change of } \\
\text { the time cycle; } \\
\text { Proportion of repeat application } \\
\text { for repair and guarantee } \\
\text { maintenance within total } \\
\text { applications; } \\
\text { Proportion of repeat application } \\
\text { for short notice repair and } \\
\text { maintenance }\end{array}$ & $\begin{array}{l}\text { Time cycle durability; } \\
\text { Total number of applications for } \\
\text { repair and guarantee } \\
\text { maintenance; } \\
\text { Number of repeat applications } \\
\text { for repair and guarantee } \\
\text { maintenance; } \\
\text { Number of applications for; } \\
\text { Short notice repair and } \\
\text { guarantee maintenance }\end{array}$ \\
\hline $\begin{array}{l}\text { 4. Analysis of the faulty } \\
\text { goods replacement rate } \\
\text { (should they be } \\
\text { delivered) }\end{array}$ & $\begin{array}{l}\text { Average rate of faulty goods } \\
\text { replacement }\end{array}$ & $\begin{array}{l}\text { Rate of faulty goods } \\
\text { replacement to individual } \\
\text { customers }\end{array}$ \\
\hline
\end{tabular}

The analysis of the after-sales service indicators commences from the customer invoicing rate, as well as final payment and differences settlement. Later analyzed is due delivered goods upgrade. Then we analyze guaranteed maintenance and repair rate and finally faulty goods replacement rate (should they be delivered).

The complex operation process indicators analysis comprises the following elements:

1. Analysis of products due delivery.

2. Analysis of production cost.

3. Analysis of the products quality compliance to customer demand.

The examples of the operation process indicator analysis for each sub-element are presented in Table 10. 
Table 10. Examples of the operation process indicator analysis

\begin{tabular}{|c|c|c|}
\hline \multirow{2}{*}{$\begin{array}{c}\text { Element of operation } \\
\text { process analysis }\end{array}$} & \multicolumn{2}{|c|}{ Indicators analyzed } \\
\hline & Outcome & Factorial \\
\hline $\begin{array}{l}\text { 1. Analysis of products due } \\
\text { delivery }\end{array}$ & $\begin{array}{l}\text { Production cycle efficiency; } \\
\text { Alternative error of products } \\
\text { delivery time to customers; } \\
\text { Proportion of late deliveries } \\
\text { within total deliveries }\end{array}$ & $\begin{array}{l}\text { Time of production cycle; } \\
\text { Time of products deliveries to } \\
\text { customers; } \\
\text { Number of late deliveries to } \\
\text { customers }\end{array}$ \\
\hline $\begin{array}{l}\text { 2. Analysis of production } \\
\text { cost }\end{array}$ & $\begin{array}{l}\text { Variance of the normal } \\
\text { (target) production cost; } \\
\text { Variance of normal (target) } \\
\text { values of various units } \\
\text { production cost }\end{array}$ & $\begin{array}{l}\text { Normal (target) production } \\
\text { cost; } \\
\text { Factorial value of } \\
\text { production cost; } \\
\text { Normal (target) values of } \\
\text { various units production cost; } \\
\text { Factorial values of various } \\
\text { units production cost }\end{array}$ \\
\hline $\begin{array}{l}\text { 3. Analysis of the products } \\
\text { quality compliance to } \\
\text { customer demand }\end{array}$ & $\begin{array}{l}\text { Number of defects per a unit } \\
\text { production million; } \\
\text { Number of faults per a unit } \\
\text { production million }\end{array}$ & $\begin{array}{l}\text { Number of defects per a unit } \\
\text { production million revealed in } \\
\text { the process of production; } \\
\text { Number of products } \\
\text { replacement, quality and } \\
\text { warranty claims; } \\
\text { Waste and products losses } \\
\text { caused by defects }\end{array}$ \\
\hline
\end{tabular}

The procedure of the operation process indicators analysis is characterized by a rigorous sequence and commences from the analysis of the products due delivery. Then analyzed are total production cost and various units' production cost. The procedure is finalized by the analysis of the products quality compliance to customer demand.

The complex elements of the innovation process analysis are the following:

1. Analysis of the new products development expediency.

2. Analysis of the applied research and development expediency and production of the next generation product feasibility study.

3. Analysis of the in-depth scientific research expediency of innovative products.

4. Analysis of the cutting-edge innovative products development feasibility study.

5. Analysis of the customer demand acceptable in terms of new products development as customer future value. 
The examples of the innovation process indicator analysis for each sub-element are presented in Table 11.

Table 11. Examples of the innovation process indicator analysis

\begin{tabular}{|c|c|c|}
\hline \multirow{2}{*}{$\begin{array}{l}\text { Element of the innovation } \\
\text { process analysis }\end{array}$} & \multicolumn{2}{|l|}{ Indicators analyzed } \\
\hline & Outcome & Factorial \\
\hline $\begin{array}{l}\text { 1. Analysis of the new products } \\
\text { development expediency }\end{array}$ & $\begin{array}{l}\text { Proportion of new products } \\
\text { immediately meeting customer } \\
\text { demand; } \\
\text { Sales losses from undue } \\
\text { marketing caused by initial } \\
\text { design adjustments }\end{array}$ & $\begin{array}{l}\text { New products promotion } \\
\text { rate; } \\
\text { Break-even time-period }\end{array}$ \\
\hline $\begin{array}{l}\text { 2. Analysis of the applied } \\
\text { research and development } \\
\text { expediency and production of } \\
\text { the next generation product } \\
\text { feasibility study }\end{array}$ & $\begin{array}{l}\text { Number of the feasible next } \\
\text { generation products } \\
\text { manufacturing }\end{array}$ & $\begin{array}{l}\text { Feasibility of production } \\
\text { process }\end{array}$ \\
\hline $\begin{array}{l}\text { 3. Analysis of the in-depth } \\
\text { scientific research expediency of } \\
\text { innovative products }\end{array}$ & $\begin{array}{l}\text { Number of innovative } \\
\text { products; } \\
\text { Proportion of innovative } \\
\text { products within sales volume; } \\
\text { New products introduction } \\
\text { opposite to planned or rival } \\
\text { product }\end{array}$ & $\begin{array}{l}\text { In-depth research and } \\
\text { development feasibility }\end{array}$ \\
\hline $\begin{array}{l}\text { 4. Analysis of the cutting-edge } \\
\text { innovative products development } \\
\text { feasibility study }\end{array}$ & $\begin{array}{l}\text { Time of the innovative product } \\
\text { development; } \\
\text { Extent of ferreted out } \\
\text { customer preferences in terms } \\
\text { of innovative products }\end{array}$ & $\begin{array}{l}\text { Number of innovative } \\
\text { products prototypes before } \\
\text { the launch }\end{array}$ \\
\hline $\begin{array}{l}\text { 5. Analysis of the customer } \\
\text { demand acceptable in terms of } \\
\text { new products development as } \\
\text { customer future value }\end{array}$ & $\begin{array}{l}\text { Approximate sales of } \\
\text { anticipated new products } \\
\text { manufactured; } \\
\text { Approximate profit from } \\
\text { anticipated new products sales }\end{array}$ & $\begin{array}{l}\text { Types of customer } \\
\text { preferences acceptable in } \\
\text { connection with new } \\
\text { products production } \\
\text { feasibility; } \\
\text { Rating of each type of } \\
\text { customer preferences } \\
\text { acceptable in connection } \\
\text { with new products } \\
\text { production feasibility; } \\
\text { Pro-forma prices for } \\
\text { anticipated new products }\end{array}$ \\
\hline
\end{tabular}




\section{Macrothink

The procedure of the innovation process indicators analysis commences, firstly, from the analysis of the new products development expediency. Secondly, the applied research and development expediency and production of the next generation product feasibility study are analyzed. The third step is to analyze in-depth scientific research expediency of innovative products and cutting-edge innovative products development feasibility study. Finally, analyzed is customer demand acceptable in terms of new products development as customer future value.

\subsection{Training and personnel development indicators analysis}

The analysis of the training and personnel development indicators is aimed at making up analytical provision for taking strategic production management decisions.

The basic elements of the training and personnel development indicators analysis are:

1. Analysis of the employees' motivation level, delegated authorities volume and the extent of conformity of their personal and corporate goals.

2. Analysis of the extent of the information system expansion.

3. Analysis of the quality of the employees training and their creative abilities development.

The examples of the training and personnel development indicators analysis are presented in Table 12. 
Table 12. Examples of the training and personnel development indicators analysis

\begin{tabular}{|l|l|l|}
\hline $\begin{array}{l}\text { Element of the training and } \\
\text { personnel development } \\
\text { analysis }\end{array}$ & \multicolumn{2}{|c|}{ Indicators analyzed } \\
\cline { 2 - 3 } $\begin{array}{l}\text { 1. Analysis of the } \\
\text { employees' motivation } \\
\text { level, delegated authorities } \\
\text { volume and the extent of } \\
\begin{array}{l}\text { conformity of their } \\
\text { personal and corporate } \\
\text { goal }\end{array}\end{array}$ & $\begin{array}{l}\text { Average number of accepted and } \\
\text { introduced innovation per an } \\
\text { employee; } \\
\text { Level of flaws uniformity and } \\
\text { permanent reduction; } \\
\text { Level of cooperation between } \\
\text { employees and organization } \\
\text { departments }\end{array}$ & $\begin{array}{l}\text { Number of employees; } \\
\text { Number of accepted and } \\
\text { introduced innovations; } \\
\text { Number of defects; } \\
\text { Number of employees, } \\
\text { whose BSC defined goal } \\
\text { are in conformity with it }\end{array}$ \\
\hline $\begin{array}{l}\text { 2. Analysis of the extent of } \\
\text { the information system } \\
\text { expansion }\end{array}$ & $\begin{array}{l}\text { Provision time of complete and } \\
\text { authentic information to assess } \\
\text { customer position as well as to } \\
\text { understand and predict the } \\
\text { demand; } \\
\text { Provision time of customer } \\
\text { information in terms of the goods } \\
\text { supplied }\end{array}$ & $\begin{array}{l}\text { Proportion of employees } \\
\text { communicating with } \\
\text { customers direct and } \\
\text { having access to the needed } \\
\text { interactive information ; } \\
\text { Portion of necessary } \\
\text { real-time data from } \\
\text { customer feedback }\end{array}$ \\
\hline $\begin{array}{l}\text { 3. Analysis of quality of } \\
\text { the employees training and } \\
\text { their creative abilities } \\
\text { development }\end{array}$ & $\begin{array}{l}\text { Percentage of key employees } \\
\text { turnover; } \\
\text { Proportion of qualified } \\
\text { employees within the total } \\
\text { personnel; } \\
\text { Labor cost at sales revenues; } \\
\text { Employees efficiency; } \\
\text { Value added per an employee; } \\
\text { Net income per an employee }\end{array}$ & $\begin{array}{l}\text { Level of employees } \\
\text { professional satisfaction; } \\
\text { Average time per an } \\
\text { employee training and } \\
\text { personnel development }\end{array}$ \\
\hline
\end{tabular}

The procedure of the BSC training and personnel development indicators analysis commences from the analysis of the employees' motivation level, delegated authorities volume and the extent of conformity of their personal and corporate goals. Ten we analyze the extent of the information system expansion. The analysis is finalized by the analysis of the quality of the employees training and their creative abilities development.

The applied strategic analysis as a new BSC research instrument of the organization economic activity defines its general contours as a new lead of scientific research and practical activity presents some kind of theoretical basis for further ASA development and above all for its practical application. 


\section{Concluding remarks}

To complete the treatment of the applied strategic analysis we draw a number of conclusions: applied strategic analysis (ASA) may be considered as a new lead of scientific research and practical application in the field of strategic organization management;

ASA concept emerged from the BSC concept development arising the need to transform a financial analysis of the organization activity into a broader and complex concept;

ASA is a BSC indicators research instrument and assumes their comparative assessment, variance diagnostics and forecast;

ASA comprises four basic leads: financial indicators analysis, customer indicators analysis, internal business-processes indicators analysis and training and personnel development indicators analysis;

ASA concept may evolve into specific methods, economic-mathematic models and software to be practically applied.

The following may be considered to be basic trends of the further applied strategic analysis development:

further ASA development assuming its elaboration and specification in terms of certain BSC elements;

ASA methods development for different companies in different industries;

ASA spread to include current activities, being BSC derivative;

economic-mathematic models and software development enabling to apply ASA practically for organization management processes.

\section{References}

Friedag, H. R., \& Schmidt, W. (2002). Balanced Scorecard: Mehr als ein Kennzahlensystem. Berlin: Haufe Mediengruppe.

Horvath \& Partners. (2004). Balanced Scorecard Umzetzen. Stuttgart: Schaeffer-Poeschel Verlag GmbH.

Kaplan, R. S. (2005). How the Balanced Scorecard Complements the McKinsey 7-s Model. Strategy and Leadership, 3(33), 41-46. http://dx.doi.org/10.1108/10878570510594442

Kaplan, R. S., \& Norton, D. P. (2006). Alignment. Using the Balanced Scorecard to Create Corporate Sinergies. Boston: Harvard Business School Press.

Kaplan, R.S., \& Norton, D.P. (2004). Measuring the Strategic Readiness of Intangible Assets. Harvard Business Review, 2(82), 52-63.

Kaplan, R. S., \& Norton, D., P. (1993). Putting the Balanced Scorecard to Work. Harvard Business Review, 5(71), 134-142. 


\section{Macrothink}

Asian Journal of Finance \& Accounting ISSN 1946-052X 2014, Vol. 6, No. 1

Kaplan, R. S., \& Norton, D. P. (2003). Strategy Maps. Boston: Harvard Business School Press.

Kaplan, R. S., \& Norton, D. P. (1992). The Balanced Scorecard: Measures That Drive Performance. Harvard Business Review, 1(70), 71-79.

Kaplan, R.S., \& Norton, D.P. (1996). The Balanced Scorecard: Translating Strategy into Action. Boston: Harvard Business School Press.

Kaplan, R. S. \& Norton, D. P. (2008). The Execution Premium: Linking Strategy to Operations for Competitive Advantage. Boston: Harvard Business School Press.

Kaplan, R. S., \& Norton, D. P. (2005) The Office of Strategy Management. Harvard Business Review, 10(83), 72-80.

Kaplan, R. S., \& Norton, D. P. (2001). The Strategy-Focused Organization: How Balanced Scorecard Companies Thrive in the New Competitive Environment. Boston: Harvard Business School Press.

Kaplan, R. S., \& Norton, D. P. (1996). Using the Balanced Scorecard as a Strategic Management System. Harvard Business Review, 1(74), 75-85.

Kaplan, R.S., Norton D. P., \& Rugelsjoen B. (2010). Managing Alliances with the Balanced Scorecard. Harvard Business Review, 1(88), 114-120.

Maisel, L. S. (1992). Performance Management: The Balanced Scorecard Approach, Journal of Cost Management, 2(6), 47-52.

Norreklit, H. (2000). The Balance on the Balanced Scorecard a Critical Analysis of Some of its Assumptions. Management Accounting Research, 1(11), 65-88. http://dx.doi.org/10.1006/mare.1999.0121

Olve, N.-G., Roy, J., \& Wetter, V. (2000). Performance Drivers: A Practical Guide to Using the Balanced Scorecard. Chichester: John Wiley \& Sons, Ltd.

Rampersad, H. K. (2003). Total Performance Scorecard: Redefining Management to Achieve Performance with Integrity. New York, NY: Butterworth Heinemann. 